\title{
Behavioural study of PEMFC during start-up/shutdown cycling for aeronautic applications
}

\author{
Noluntu Dyantyi ${ }^{1} \cdot$ Adrian Parsons $^{1} \cdot$ Piotr Bujlo $^{1} \cdot$ Sivakumar Pasupathi $^{1}$
}

Received: 3 August 2018 / Accepted: 4 January 2019 / Published online: 11 January 2019

(c) The Author(s) 2019

\begin{abstract}
The deployment of proton exchange membrane fuel cell (PEMFC) for aeronautic applications is a value-added energy supply alternative that not only generates useful byproducts (oxygen-depleted air, water and heat) but addresses sensitive issues such as improving health conditions of airport personnel (silent operation minimizes noise) and decreasing greenhouse gas emission (in situ zero emissions). However, the PEMFC is yet to be industrialized due to its fast degrading components. The contribution of the several start-ups and shutdowns (a PEMFC undergoes when operated in aircraft) to the degradation is not well-understood. Hence, this study seeks to explore the effects of start-up/shutdown (SU/SD) cycling on a PEMFC's lifetime. The SU/SD cycling is incorporated with heating to $60^{\circ} \mathrm{C}$ and cooling to room temperature to mimic real-life temperature changes encountered in an aircraft. The tested membrane electrode assemblies (MEAs) were characterised for performance and evolution of its components to examine the extent and nature of degradation. More than two-thirds loss of electrochemically active surface area (ECSA) of catalyst, Pt particle growth $(4.71-6.41 \mathrm{~nm})$ associated with Ostwald ripening and formation of $\mathrm{PtO}$ from adsorption of $\mathrm{OH}^{-}$by $\mathrm{Pt}-\mathrm{M}$ surface were identified to be causes of the observed voltage decay at $0.196 \mathrm{mV} \mathrm{h}^{-1}$ rate. Hence, it is concluded that SU/SD cycling mostly affects the catalytic component of PEMFC in the aeronautic environment.
\end{abstract}

Keywords Proton exchange membrane fuel cells $\cdot$ Degradation $\cdot$ Accelerated stress tests $\cdot$ Aeronautic environment $\cdot$ Load profile $\cdot$ State of health

\section{Introduction}

The PEMFC is a device that operates silently and comprises of solid electrolyte and no moving parts [1,2]. The PEMFC converts chemical energy from the electrochemical reaction of oxygen and hydrogen into electrical while emitting heat, oxygen-depleted air (ODA) and water as byproducts. These byproducts have useful functions in aircrafts, such as de-icing wing and heating water using emitted heat, fire retardation with the ODA and water generation on board [3]. Furthermore, the PEMFC is an auxiliary power unit (APU) that powers small electrical systems on-board such

Noluntu Dyantyi

3174867@myuwc.ac.za

1 Hydrogen South Africa (HySA) Systems Integration and Technology Validation Competence Centre, South African Institute for Advanced Materials Chemistry, University of the Western Cape, Private Bag X17, Bellville 7535, South Africa as environmental control systems (ECS), in-flight entertainment and recharging batteries [4].

A study by Klebanoff et al. showed that PEMFC could successfully replace the ram air turbine (RAT) emergency backup power system [5]. Hence, leading aircraft manufacturers are working on PEMFC-powered propulsions and APUs as part of establishing "more-electric airplanes" [1, 6]. The "more-electric airplanes" will replace the pneumatically powered and hydraulically powered systems (e.g., ECS and cargo doors) with lighter and more efficient electric systems [7]. Consequently, PEMFC is tested for various aeronautic applications, ranging from nose wheel drive motor, hybrid with batteries, exclusively powering small manned aircrafts to emergency power systems [8-11].

Developments in field and in-flight testing of PEMFCpowered aircrafts includes improving from a hybrid of $20 \mathrm{~kW}$ PEMFC with batteries to exclusively $33 \mathrm{~kW}$ PEMFC and reaching $1000-2558 \mathrm{~m}$ altitude without significant performance loss $[8,12]$. The success observed in field testing propelled further testing of PEMFC in laboratory-simulated 
aeronautic conditions. The laboratory-simulated aeronautic conditions examined include orientation/inclination and high altitude/low pressure [3, 13-16]. For instance, the effects' inclinations on PEMFC performance were notable when the fuel cells were operated at a low cathode stoichiometry of 1.6 [17]. The notable PEMFC performance losses at high altitude/low pressure $(0.7 \mathrm{bar} / 2200 \mathrm{~m}$ altitude) were minimized by increasing the cathode stoichiometry to 1.75 and 2.5 at $1200 \mathrm{~m}$ and $2200 \mathrm{~m}$ altitude, respectively [16, 18-20]. However, the concerns of increasing cathode stoichiometry to more than 2.5 were membrane drying and power consumption by compressors [19]. The study by Keim et al. and Werner et al. on the quality of the cathode-discharged ODA gas achieved the desired less than 12\% ODA oxygen content by operating the fuel cell at $2000 \mathrm{~m}, 60{ }^{\circ} \mathrm{C}$ cell temperature and a high cathode stoichiometry of 3.6 [15, 16, 21]. Again, cathode stoichiometry above 2.5 may damage the stack. Hence, the increase of cathode stoichiometry to 2.5 is taken as an adequate measure to minimize performance losses due to low ambient pressure $(0.7$ bar at $2200 \mathrm{~m})$ and low oxygen content $(16.0 \%$ at $2200 \mathrm{~m})$ at high altitudes.

It is safe to say (from the literature survey presented above) that operating and environmental/surrounding conditions have been relatively studied with respect to their effect on PEMFC performance, except for load profile. The typical load profile for aircrafts is as follows: ground taxi, take-off and climb, cruise, descend and landing and ground taxi [4]. Exploring the effects of load profile-related operating conditions on PEMFC performance under aeronautics conditions is essential in enabling the deployment of fuel cells in the aeronautic sector.

Lifetime studies under normal operating conditions are rarely conducted due to time and resource constraints. Hence, fuel cells are tested under conditions that accelerate performance loss and degradation rates using accelerated stress tests (AST) protocols. AST apply different accelerated stressors to determine and predict the durability of fuel cell components by examining known failure mechanisms and major precursors of failure. Each of the AST protocols is designed to focus on a specific fuel cell component. For instance, open circuit voltage (OCV) facilitates chemical attack of the perfluorosulfonic acid (PSFA) membrane by peroxide radicals, whereas relative humidity $(\mathrm{RH})$ cycling causes mechanical degradation of the membrane [5, 22-25]. One of the load profile-related AST that is relevant to aeronautic applications is SU/SD cycling.

Factors that influence fuel cell lifetime under aeronautical conditions are operating temperature, $\mathrm{RH}$ and reactants' stoichiometry. In real-world applications, PEMFC is subjected to more than one stressor, either concurrently or simultaneously. De Bruijn's review eloquently demonstrates how a combination of different stressors contributes towards each fuel cell component's degradation [26]. Kim et al. showed that $\mathrm{RH}$ has no significant effect during SU/SD, except at $100 \%$ RH [27].

A study by Pei et al. profiled the life expression of a bus driven $43,000 \mathrm{~km}$ on a fixed route daily, particularly loadchanging cycles, start-up/shutdown cycles, idling cycles and high power conditions [28]. The start-stop cycling, with start-up operating conditions at $60{ }^{\circ} \mathrm{C}, 1.2 / 2.5 \mathrm{Sa} / \mathrm{Sc}$, $357 \mathrm{~mA} \mathrm{~cm}^{-2}$, idling for $1 \mathrm{~min}$ at $10 \mathrm{~mA} \mathrm{~cm}{ }^{-2}$, stop and purge with nitrogen until voltage was zero, caused major degradation. The degradation was attributed to high OCV. Even though there was a follow-up publication by Pei et al. on post-mortem analysis of the membrane electrode assemblies (MEAs), chemical and physical transformations of the fuel cell components caused by the degradation were not examined by common techniques such as SEM, TEM or XRD [29].

SU/SD cycling reported in literature examines the effect of load changes at a fixed temperature, which is not necessarily representative of the actual start-up or shutdown, as heating and cooling occur concurrently. Hence, the aim of this study is to evaluate the behaviour of PEMFC operated at $60{ }^{\circ} \mathrm{C}$ and exposed to SU/SD with heating and cooling as it would happen during aircraft operation. The PEMFC was characterised for the extent and nature of degradation to better understand its behaviour in the aeronautic environment.

\section{Materials and methods}

\section{Setup}

The low-temperature PEMFC single cell (see Fig. 1) used for testing consisted of a $25 \mathrm{~cm}^{2}$ commercial MEA, assembled in a commercial single cell fixture made of graphite bipolar plates with a serpentine/parallel flow pattern design and gold-plated current collectors. Both anode and cathode catalyst loadings were $1.0 \mathrm{mg} \mathrm{cm}^{-2} \mathrm{Pt}$.

The single cell was tested using the Greenlight G20 Fuel Cell Test Station. The fuel cell was operated at atmospheric pressure with pure hydrogen and air supplied to the anode and cathode, respectively. The stoichiometry used was $1.8 / 2.5$ for the anode and cathode. The MEA was activated by applying a constant voltage of $0.7 \mathrm{~V}$ to a cell operating at $60{ }^{\circ} \mathrm{C}$, supplied with fully humidified $(100 \% \mathrm{RH})$ reactants, at anode/cathode stoichiometry of $1.8 / 2$ for $100 \mathrm{~h}$. Fuel cell parameters such as operating temperature, dew point, stoichiometry/flow rates and load were controlled using Greenlight's Emerald ${ }^{\mathrm{TM}}$ control and automation software.

\section{Test conditions}

The MEA was subjected to SU/SD cycling with heating and cooling to mimic aeronautic conditions as shown in 
Fig. 1 Components of the single cell used in this study and schematic illustration of reactants' flow and chemical reactions taking place
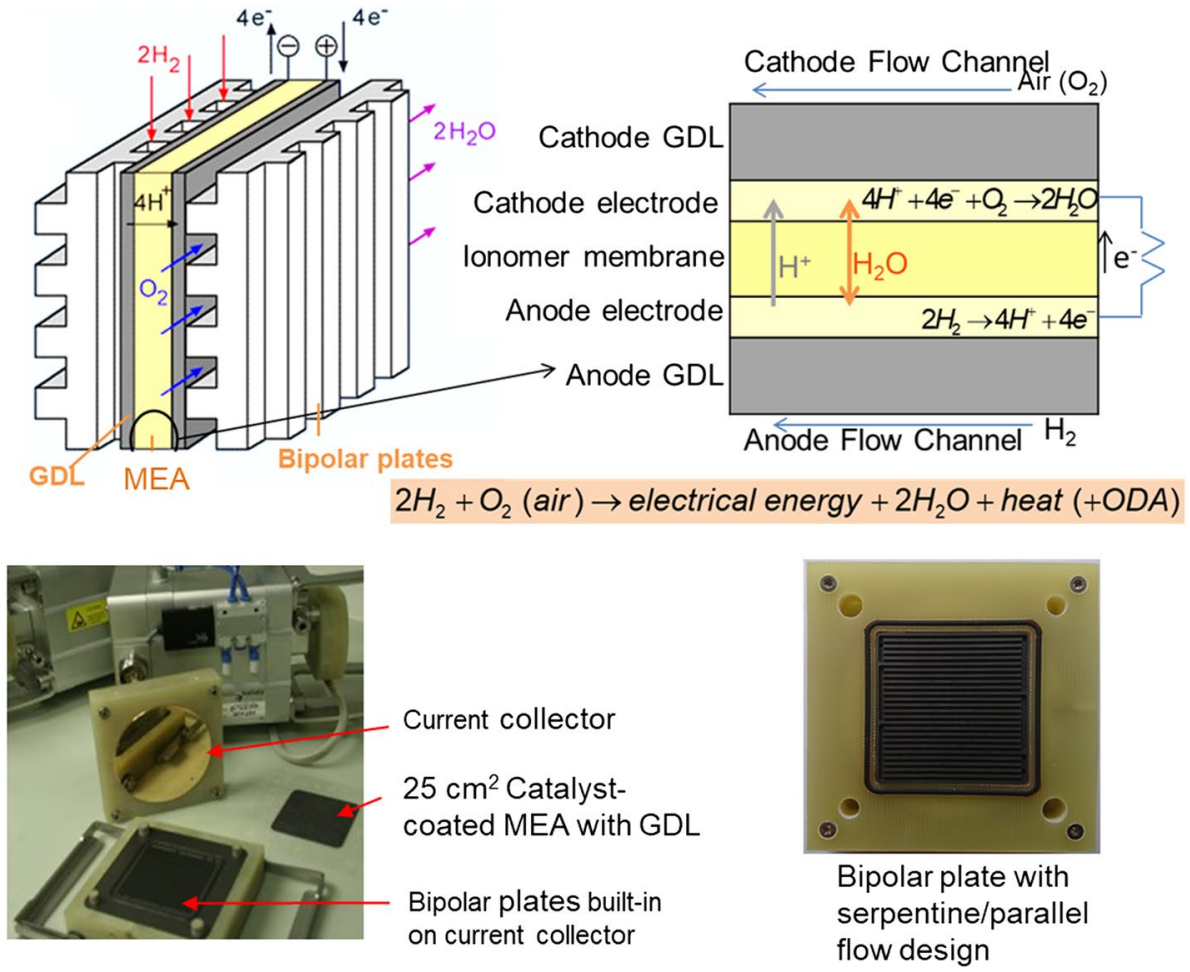

Fig. 2 Schematic diagram of SU/SD cycle (heating up to $60{ }^{\circ} \mathrm{C}$ and cooling down to room temperature) used during experimental part of the work. A voltage of $0.7 \mathrm{~V}$ was imposed during the heating and cooling. Voltage was measured at the imposed current when measuring IV curve and purging

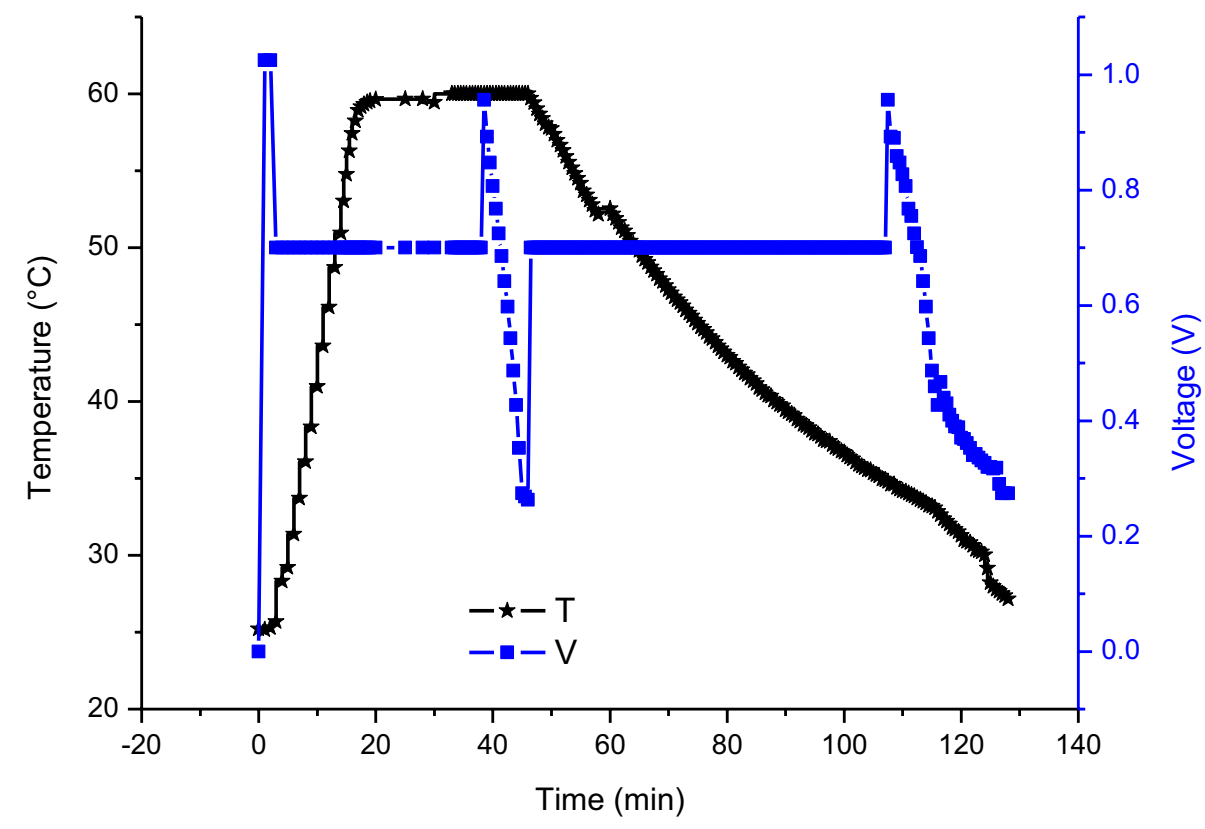

Fig. 2. The single cell was heated to $60{ }^{\circ} \mathrm{C}$ at $0.7 \mathrm{~V}, 100 \%$ $\mathrm{RH}$ and 1.8/2.5 anode/cathode stoichiometric ratio. When the fuel cell reached $60{ }^{\circ} \mathrm{C}$ and stabilized for $15 \mathrm{~min}$, a polarization (IV) curve was taken and the cell was cooled to room temperature, followed by $5 \mathrm{~min}$ rest prior to restart. The cell was purged with nitrogen for only $5 \mathrm{~min}$ at the end of each cycle to minimize hydrogen/air interface until voltage reaches zero since purging is impractical in real operation of aircraft fuel cells.

\section{Electrochemical analysis}

An IV curve provides information on overall fuel cell performance and is used to estimate the overall degradation 
rate using voltage decay over test duration. The IV curves were measured using the Emerald ${ }^{\mathrm{TM}}$ software test station in galvanostatic mode from 0.0 to $0.7 \mathrm{~mA} \mathrm{~cm}{ }^{-2}$. Operating conditions were kept similar to the SU/SD cycling with $60{ }^{\circ} \mathrm{C}$ cell temperature, $65{ }^{\circ} \mathrm{C}$ dew point temperature and 1.8/2.5 stoichiometric ratio. The results obtained were used to compute the average degradation rate (ADR) by calculating the difference between initial and final voltage over the test duration using Eq. 1:

$\mathrm{ADR}=\frac{\text { Initial voltage }- \text { Final voltage }}{\text { Test duration }}$.

The fresh and tested MEAs were characterised for electrochemical properties using cyclic voltammetry (CV). The CV measurements were taken using the Autolab PGSTAT302N potentiostat with FRA2 module controlled by Nova software. The $\mathrm{CV}$ was measured at $30^{\circ} \mathrm{C}$, a voltage range of $0.015-1.00 \mathrm{~V}$ and a sweep rate of $30 \mathrm{mV} \mathrm{s}^{-1}$. The gas supply for the $\mathrm{CV}$ was hydrogen and nitrogen at anode and cathode, respectively.

\section{Chemical/physical analysis}

Small pieces were cut out from the MEAs and characterised using high-resolution scanning electron microscopy coupled with energy-dispersive spectroscopy (HR-SEM/EDS) and $\mathrm{X}$-ray diffraction (XRD). ZEISS MERLIN HR-SEM/EDS was used to characterise cross-sections of the MEAs for chemical composition and particle migration/redeposition. Bruker D8 high-resolution X-ray diffractometer with Vantec detector was used to analyse the crystal structure, phase purity and particle size distribution (PSD). Electrode powder samples were also examined for changes in the structure of the catalyst layer by capturing Pt transformation due to particle migration, particle growth from agglomeration and changes in the structure of the membrane surface. This was done through the use of high-resolution transmission electron microscopy (HR-TEM) and HR-SEM/EDS. The HRTEM used was Hitachi H800 $200 \mathrm{kV}$ instrument fitted with a digital image acquisition system.

\section{Results and discussions}

\section{Overall performance}

PEMFC performance is a measure of the ability of fuel cells to generate the required power output. Overall degradation, however, is quantified as the rate of voltage decay. The fuel cell was subjected to $600 \mathrm{SU} / \mathrm{SD}$ cycles that took $120 \mathrm{~min}$ each and the voltage measured at $400 \mathrm{~mA} \mathrm{~cm}^{-2}$ decreased from $0.3359-0.1003 \mathrm{~V}$, with a degradation rate of 0.196 $\mathrm{mV} \mathrm{h}^{-1}$. Figure 3 shows the recorded changes in voltage

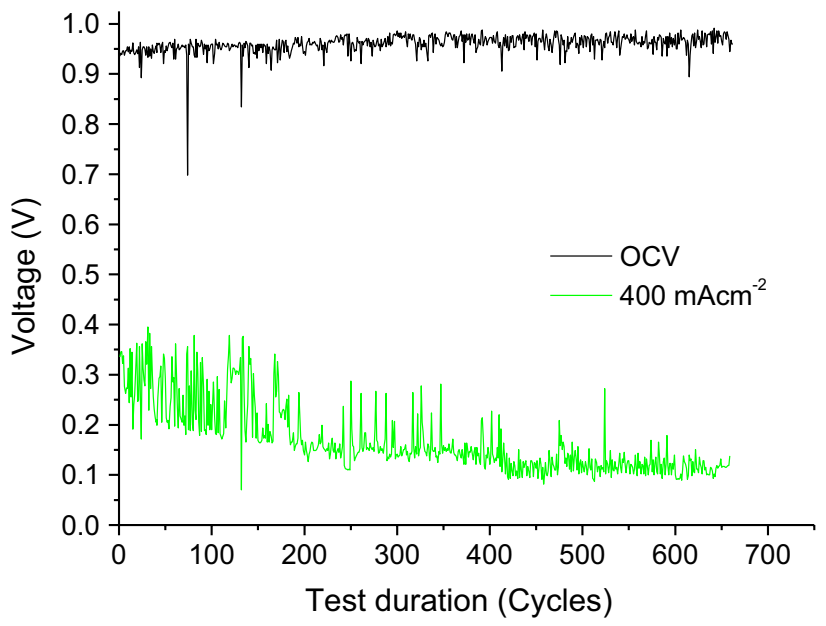

Fig. 3 Voltage evolution at OCV and $400 \mathrm{~mA} \mathrm{~cm}{ }^{-2}$ during SU/SD cycling carried out between room temperature and $60{ }^{\circ} \mathrm{C}$ for 600 cycles at $100 \% \mathrm{RH}$, atmospheric pressure and stoichiometric ratio of $1.8 / 2.5$ anode/cathode

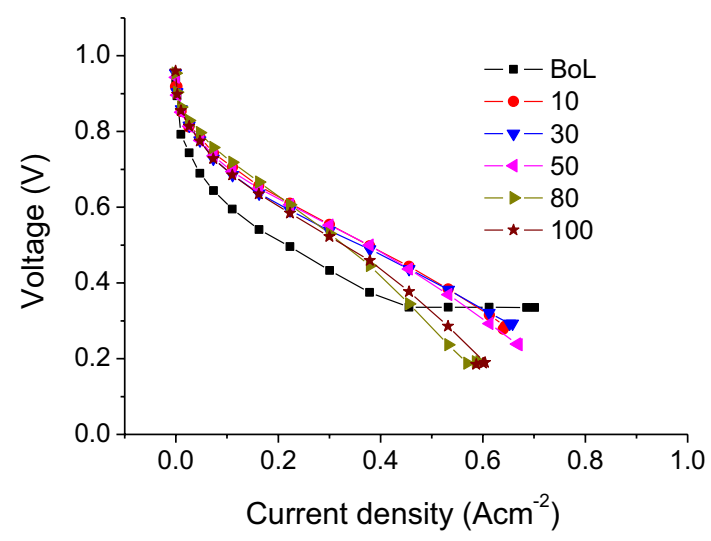

Fig. 4 The IV curves taken within the first 100 SU/SD cycles at random intervals. The IV curves were measured at $60{ }^{\circ} \mathrm{C}, 100 \% \mathrm{RH}$, atmospheric pressure and stoichiometric ratio of 1.8/2.5 anode/cathode

at $\mathrm{OCV}$ and $400 \mathrm{~mA} \mathrm{~cm}^{-2} .400 \mathrm{~mA} \mathrm{~cm}^{-2}$ (equivalent to 10 A) was chosen as the current density representative of the ohmic loss region according to polarization curve diagram. Voltage decay was more apparent at higher current density relative to when there was no current drawn. Similarly to Kim et al. and Jo et al., voltage loss at the OCV region was minute $[27,30]$. The insignificant voltage decay at the activation region suggests minor changes in kinetics of oxygen reduction reaction (ORR), implying that there are no perforations in the membrane [31].

The IV curve of a pristine MEA recorded prior to the test is regarded as beginning of life (BoL). Figure 4 demonstrates a performance improvement observed during the first 100 cycles. The peak in current at the beginning of the tests may 


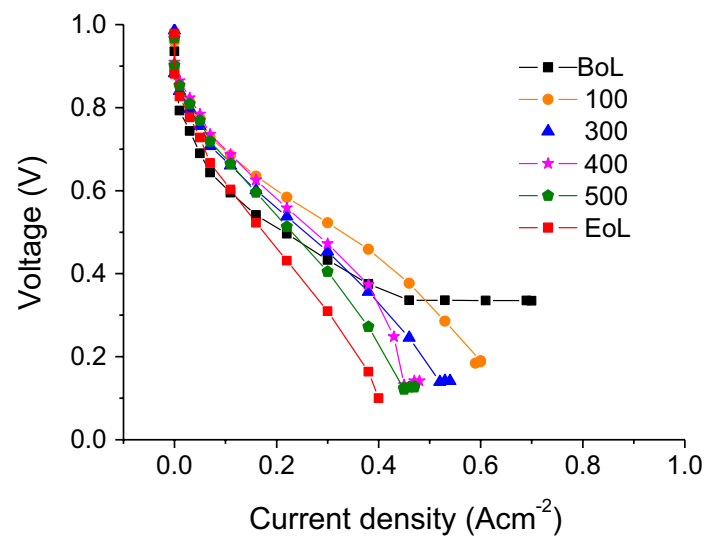

Fig. 5 The IV curves of the fuel cell prior to and after the SU/SD cycling test at $60{ }^{\circ} \mathrm{C}, 100 \% \mathrm{RH}$ and $1.8 / 2.5$ anode/cathode stoichiometry

be due to continued MEA activation. On the other hand, a significant performance drop was observed immediately after 100 cycles at high current densities and voltage continued to drop until the end of the test (EoL), 600 cycles as shown in Fig. 5.

The sudden decrease observed after 100 cycles at high current densities may be caused by mass transport limitations, since PEMFC requires a higher active surface area to meet the demand of the chemical reactions compared to low current densities [32]. Kim et al. also reported that full humidification may lead to excess water that blocks the electrode surface area and subsequently results in temporary reactants' starvation [27]. The review by Yu et al. highlighted that SU/SD degradation is minimal at low temperatures and humidity [33]. Given that the rate of water generation is much faster at high current density compared to low current density, the IV curves results attest that higher humidity introduces additional water into the cell that causes flooding and subsequently promotes degradation. Full humidification was chosen as a worse-case scenario in this study, since PEMFCs operating in aeronautic conditions are likely to be periodically flooded due to varying load demands.

\section{Electrochemical evolution}

The CV was employed as a complimentary in situ electrochemical technique to the IV curve, since it provides information on the catalyst activity. Linse et al. discovered that voltage loss after SU/SD cycling was due to mass transport limitations and the formation of isolated electrode areas/Pt agglomeration [34]. The latter reflects electrode degradation, which is associated with high voltage and starvation caused by flooding. As a result, the fuel cell was characterised for catalyst activity using CV. Expectedly so, the voltammograms in Fig. 6 show a significant loss of catalyst activity after 600 cycles, taken as end of life (EoL).

The CV data was further processed to estimate ECSA through Eq. 2. The ECSA was 58.88 and $22.56 \mathrm{~cm} \mathrm{~g}^{2}$ $\mathrm{Pt}(\mathrm{gPt})^{-1}$ at beginning and end of tests, respectively. The calculation showed that more than two-thirds of catalyst activity was lost:

$\mathrm{ECSA}=\frac{Q}{210 \times 10^{-3} \times \text { Ptloading }}$,

where $Q$ represents the charge $\left(\mathrm{mC} \mathrm{cm}^{-2}\right)$ associated with the hydrogen adsorption/desorption, $\mathrm{Pt}$ loading is the loading of platinum at the studied electrode $\left(\mathrm{gPt} \mathrm{cm}^{-2} \mathrm{Pt}\right)$, $210 \times 10^{-3}$ is the hydrogen adsorption/desorption charge $\left(\mathrm{mC} \mathrm{cm}{ }^{-2} \mathrm{Pt}\right)$ on a smooth Pt electrode.

\section{Exploration of degradation mechanisms}

To examine the cause of fuel cell performance and ECSA losses, changes in PSD of cathode Pt/C catalysts were analysed through HR-TEM and XRD. The micrographs and diffractograms were taken before and after SU/SD cycling, as shown in Figs. 7 and 8, respectively.

The PSD shown in Fig. 9 was estimated by calculating the average particle diameter using ImageJ software and qualitatively through observing peak properties of the diffractograms. ImageJ software takes into account the known scale, resolution and magnification in which HR-TEM images were measured.

High voltages favour platinum dissolution and Wang et al. observed a higher concentration of Pt at 0.9 V [36]. On the other hand, Pt particles are easily redeposited at reverse current conditions created by the SU/SD [30]. Due to high equilibrium potential of dissolution, $\mathrm{Pt}$ ions tend to redeposit

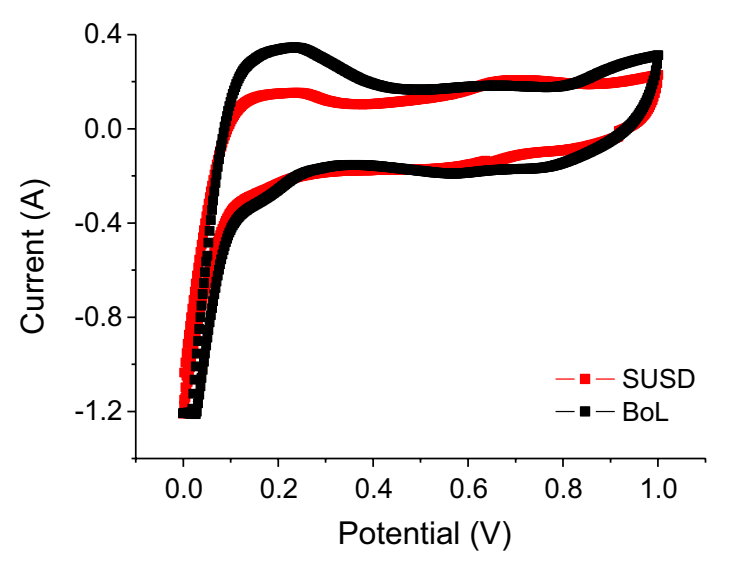

Fig. 6 Cyclic voltammetry of a fresh (BoL) and tested MEA (SUSD) measured at $30{ }^{\circ} \mathrm{C}, 100 \% \mathrm{RH}$ and a voltage range of $0.015-1.00 \mathrm{~V}$ and a sweep rate of $30 \mathrm{mVs}^{-1}$. The anode and cathode were supplied with hydrogen and nitrogen gases

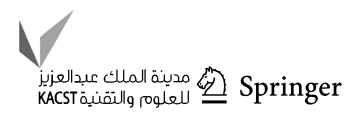


Fig. 7 HR-TEM micrographs of fresh (BoL) and tested (EoL) cathode catalysts
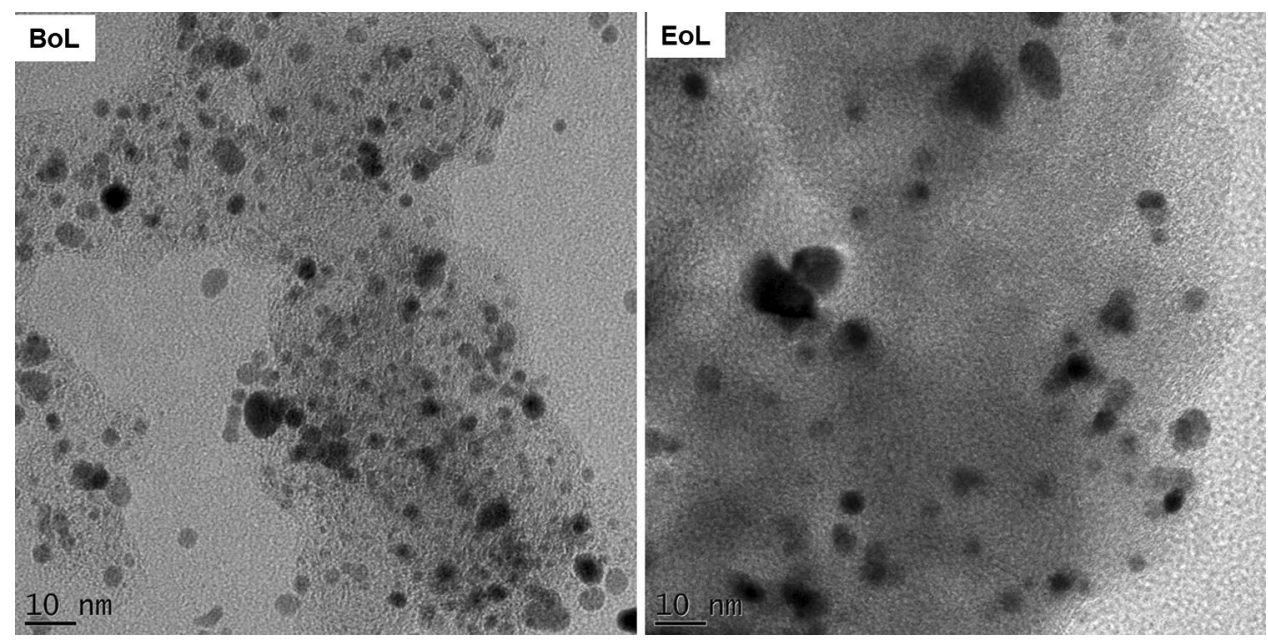

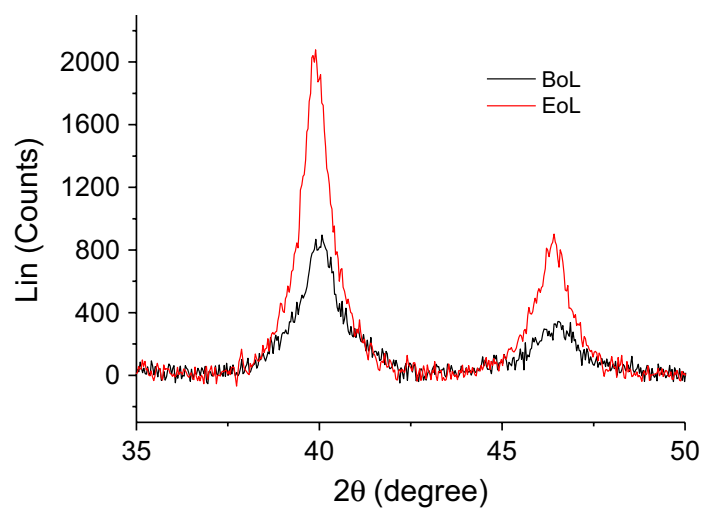

Fig. 8 XRD patterns of cathode before (BoL) and after SU/SD cycling (EoL)

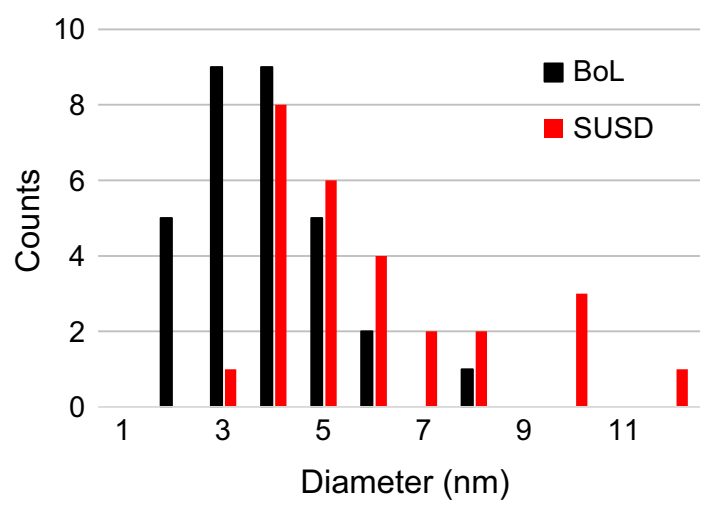

Fig. 9 Relative particle size distribution of Pt particles at beginning of life (BoL) and after SU/SD cycling (EoL)

onto larger Pt particles in the cathode and thus undergo Ostwald ripening to minimize surface energy [37]. Hence, the increased average particle size from 4.71 to $6.41 \mathrm{~nm}$ (Fig. 9) and HR-TEM micrographs (Fig. 7) suggest that the particles experienced Ostwald ripening, migration/dissolution and redeposition. Zhao et al. noted that narrower XRD peaks indicate larger Pt particles [35]. The particle growth corresponds to the loss of ECSA (Fig. 6) and narrower XRD peaks (Fig. 8). Therefore, Pt particle agglomeration may be attributed to a loss of ECSA and be one of the causes of voltage decay.

An additional reason for ECSA loss may be the adsorption of $\mathrm{OH}^{-}$on Pt-M surfaces which forms PtO. Pt sintering mostly occurs at cathode due to chemical oxidation of Pt into PtO by residual oxygen present in the cathode layer, following the mechanism in Eqs. 3 and 4 [38]. The hydrogen and oxygen presence may be due to the short time of purging, since IV curves data hinted no signs of crossover:

$\mathrm{Pt}^{2+}+\mathrm{H}_{2} \rightarrow \mathrm{Pt}+2 \mathrm{H}^{+}$,

$\mathrm{Pt}+1 / 2 \mathrm{O}_{2} \rightarrow \mathrm{PtO}$.

Loose Pt particles, due to a collapse of support, move freely and redeposit either on other Pt particles or on the membrane. The latter was neither notable nor studied further due to unnoticeable membrane degradation and being limited by the scope of this research. The former has been shown by the different analytical techniques used in this study, such as HR-TEM and XRD to be demonstrating Pt particle growth.

The observed delamination on cross-section in Fig. 9 supports the hypothesis of loose Pt particles due to carbon corrosion. Turquoise Pt and purple S particles in Fig. 10 are visible on all the layers captured by HRSM/EDS at EoL, implying migration and redeposition.

Therefore, the loss of ECSA may be partly attributed to carbon support corrosion.

Table 1 contains elemental compositions of the pristine and tested MEAs as acquired from HR-SEM/EDS. The presence of oxygen on the tested MEA substantiates the occurrence of the reactions outlined in Eqs. 3 and 4 above. The 
Fig. 10 HR-SEM/EDS layered image of MEA's cross-section before $(\mathrm{BoL})$ and after $(\mathrm{EoL})$ SU/SD cycling
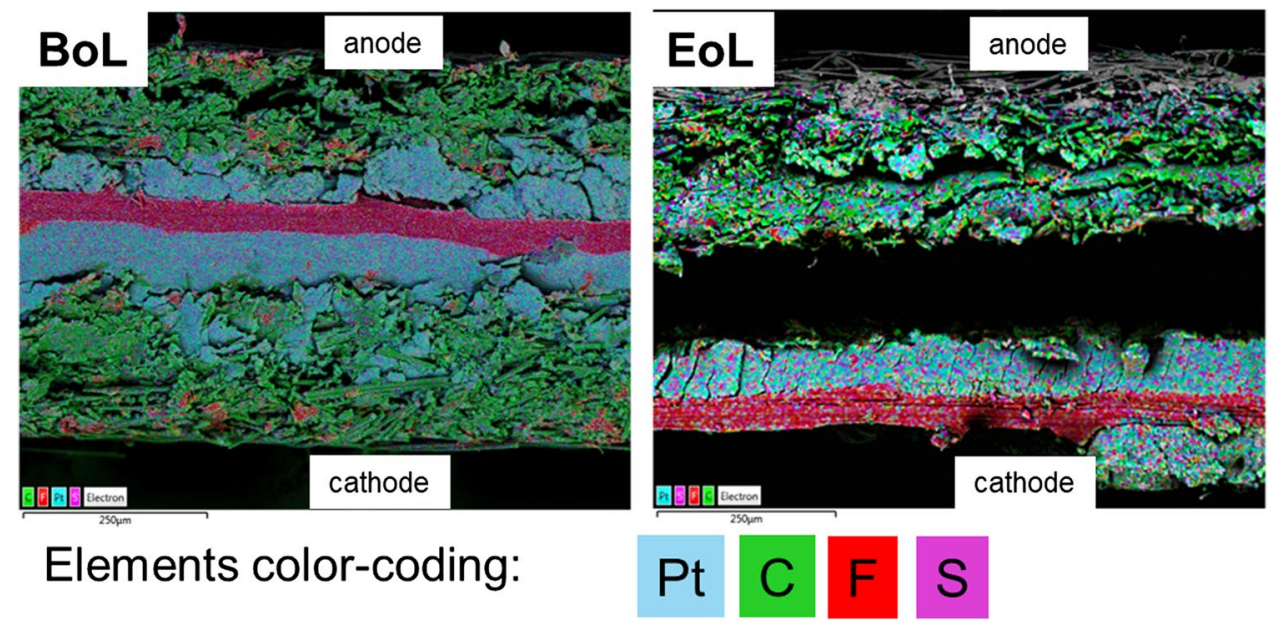

Table 1 Elemental composition of a pristine and tested MEA as obtained from HR-SEM/EDS

\begin{tabular}{lcc}
\hline Test/element & BoL $(w t \%)$ & EoL $(w t \%)$ \\
\hline Carbon & 70.07 & 59.42 \\
Fluoride & 2.96 & 7.95 \\
Sulphur & 0.72 & 0.66 \\
Platinum & 26.26 & 27.21 \\
Oxygen & - & 4.76 \\
\hline
\end{tabular}

minute change in concentrations proves that $\mathrm{Pt}$ did not leach out but rather migrated and redeposited.

Carbon leached out after 600 cycles (EoL), which indicates corrosion of the catalyst support. Carbon support corrosion is prevalent at high voltage [28, 39]. Flooding, as likely to occur at high current densities for a fully humidified cell exposed to variable load demands, is reportedly blocking catalyst reactive sites and promotes carbon corrosion [40, 41]. Pt agglomeration tends to be aggravated by carbon corrosion. Therefore, the loss of ECSA may be partly attributed to carbon support corrosion.

\section{Conclusion}

The aim of this study was to examine the effect of SU/SD cycling on the performance of PEMFC operating in an aeronautic environment. The aeronautic environment was simulated by incorporating heating to $60^{\circ} \mathrm{C}$ and cooling to room temperature while operating at 1.8:2.5 anode/cathode stoichiometric ratio. This specific stoichiometric ratio was selected, because increasing cathode to 2.5 minimizes performance loss associated with high altitudes and improves quality of ODA for multifunctional fuel cells.
The ultimate objective of this research was to collect and document AST data relevant to aeronautic applications. In doing so, understanding of PEMFC behaviour in an aeronautic environment will be enhanced and thus its performance and state of health can be better managed.

The studied MEA was characterised for overall performance and ECSA using the IV curve and the CV. Physical and chemical properties such as elemental composition and particle size distribution were evaluated using HR-SEM/ EDS, XRD and HR-TEM.

Voltage evolution recorded during the test showed average degradation of $0.196 \mathrm{mV} \mathrm{h}^{-1}$. The loss of ECSA revealed that the observed performance loss may be attributed to catalyst degradation. Furthermore, Pt particle agglomeration (shown by increased average particle size) suggests that $\mathrm{Pt}$ redeposition is one of the causes of loss of ECSA, which is evidence for catalyst degradation. The presence of oxygen from the HR-SEM/EDS results proves oxidation of $\mathrm{Pt}$ into $\mathrm{PtO}$ which covers the catalyst surface area and hinders the chemical reactions from taking place. Thus, it can be concluded that SU/SD-induced degradation on PEMFC operated in aeronautic conditions is caused by catalyst degradation in the form of Pt particle agglomeration due to redeposition and oxidation of $\mathrm{Pt}$ into PtO.

Acknowledgements This work is supported by Hydrogen and Fuel Cell Technologies RDI Programme (HySA), funded by the Department of Science and Technology in South Africa (Project KP3-S03).

Open Access This article is distributed under the terms of the Creative Commons Attribution 4.0 International License (http://creat ivecommons.org/licenses/by/4.0/), which permits unrestricted use, distribution, and reproduction in any medium, provided you give appropriate credit to the original author(s) and the source, provide a link to the Creative Commons license, and indicate if changes were made. 


\section{References}

1. Seidel Jonathan, A., Sehra Arun, K., Colantonio Renato, O.: NASA aeropropulsion research: Looking forward. NASA, Glenn Research Center, Cleveland (2001)

2. Friedrich, K.A., et al.: Fuel cell systems for aircraft application. ECS Trans. 25, 193-202 (2009)

3. Renouard-Vallet, G., et al.: Fuel cells for civil aircraft application: on-board production of power, water and inert gas. Chem. Eng. Res. Design 90, 3-10 (2012)

4. Pratt, J.W., et al.: Proton exchange membrane fuel cells for electrical power generation on-board commercial airplanes. Appl. Energy 101, 776-796 (2013)

5. Klebanoff, L.E., Cornelius, C.J.: Analysis of hydrogen storage for a fuel cell emergency power system (FCEPS) for commercial aircraft. In: Annual Merit Review and Peer Evaluation Meeting, 9-13 May, Arlington, Virginia (2011)

6. Daggett, D. L., Eelman, S. and Kristiansson, G.: Fuel cell APU for commercial aircraft. In: AIAA/ICAS International air and space symposium and exposition: the next 100 years, 14-17 July, Dayton, Ohio, pp. 1-9 (2003)

7. Eelman, S., del Pozo y de Poza, I., Krieg, T.: Fuel cell APU's in commercial aircraft-an assessment of SOFC and PEMFC concepts. In: 24th International congress of the aeronautical sciences, 29 Aug-3 Sept, Yokohama, Japan, pp. 1-10 (2004)

8. Lapeña-Rey, N., et al.: Environmentally friendly power sources for aerospace applications. J. Power Sources 181, 353-362 (2008)

9. Romeo, G.: The First European Commision Funded aircraft powered by a hydrogen fuel cell took its first flight. https://fuelcellsw orks.com/archives/2010/06/15/first-european-commission-funde d-aircraft-powered-by-a-hydrogen-fuel-cell-takes-first-flight/ (2010). Accessed 23 July 2015

10. DLR International Press Release: DLR Airbus A320 ATRA taxis uses fuel cell-powered nose wheel for the first time. Available from: http:// www.dlr.de/dlr/presse/en/desktopdefault.aspx/tabid-10307/470_read931/year-2011/\#/gallery/2079 (2011). Accessed 11 June 2015

11. Boeing International Press Release.: 787 electrical system. Available from: http://787updates.newairplane.com/787-Electrical-Syste ms/787-Electrical-System (2013). Accessed 11 June 2015

12. Rathke, P., et al.: Long distance flight testing with fuel cell powered aircraft antares DLR-H2. https://www.dglr.de/publikatio nen/2014/301219.pdf (2013). Accessed 11 June 2015

13. Rouss, V., et al.: Mechanical behaviour of a fuel cell stack under vibrating conditions linked to aircraft applications part I: experimental. Int. J. Hydrogen Energy 33, 6755-6765 (2008)

14. Bégot, S., et al.: Fuel cell climatic tests designed for new configured aircraft application. Energy Convers. Manage. 51, 1522-1535 (2010)

15. Keim, M., et al.: Multifunctional fuel cell system in an aircraft environment: an investigation focusing on fuel tank inerting and water generation. Aerosp. Sci. Technol. 29, 330-338 (2013)

16. Werner, C., et al.: Characteristics of PEMFC operation in ambientand low-pressure environment considering the fuel cell humidification. CEAS Aeronaut. J. 6, 1-15 (2014)

17. Renouard-Vallet, G., et al.: Improving the environmental impact of civil aircraft by fuel cell technology: concepts and technological progress. Energy Environ. Sci. 3, 1458-1468 (2010)

18. Uno, M., et al.: Development and demonstration flight of a fuel cell system for high-altitude balloons. J. Power Sources 193, 788-796 (2009)

19. Hordé, T., Achard, P., Metkemeijer, R.: PEMFC application for aviation: experimental and numerical study of sensitivity to altitude. Int. J. Hydrogen Energy 37, 10818-10829 (2012)

20. Kallo, J., et al.: Fuel cell system development and testing for aircraft applications, in 18th World Hydrogen Energy Conference, 16-21 May, pp. 435-444. Essen, Germany (2010)
21. Werner, C., Busemeyer, L., Kallo, J.: The impact of operating parameters and system architecture on the water management of a multifunctional PEMFC system. Int. J. Hydrogen Energy 40, $11595-11603$ (2015)

22. Inaba, M., et al.: Gas crossover and membrane degradation in polymer electrolyte fuel cells. Electrochim. Acta 51, 5746-5753 (2006)

23. Makharia, R., et al.: Durable PEM fuel cell electrode materials: requirements and benchmarking methodologies. ECS Trans. 1, $3-18$ (2006)

24. Tang, H., et al.: A degradation study of Nafion proton exchange membrane of PEM fuel cells. J. Power Sources 170, 85-92 (2007)

25. Zhang, S., et al.: Effects of open-circuit operation on membrane and catalyst layer degradation in proton exchange membrane fuel cells. J. Power Sources 195, 1142-1148 (2010). https://doi. org/10.1016/j.jpowsour.2009.08.070

26. de Bruijn, F.A., Dam, V.A.T., Janssen, G.J.M.: Review: durability and degradation issues of PEM fuel cell components. Fuel Cells 8, 3-22 (2008)

27. Kim, J.H., et al.: Effects of cathode inlet relative humidity on PEMFC durability during startup-shutdown cycling. J. Electrochem. Soc. 157, B104-B112 (2010)

28. Pei, P., Chang, Q., Tang, T.: A quick evaluating method for automotive fuel cell lifetime. Int. J. Hydrogen Energy 33, 3829-3836 (2008)

29. Pei, P., et al.: Analysis on the PEM fuel cells after accelerated life experiment. Int. J. Hydrogen Energy 35, 3147-3151 (2010)

30. Jo, Y.Y., et al.: Degradation of polymer electrolyte membrane fuel cells repetitively exposed to reverse current condition under different temperature. J. Power Sources 196, 9906-9915 (2011). https://doi.org/10.1016/j.jpowsour.2011.08.035

31. Shan, J., et al.: Local resolved investigation of PEMFC performance degradation mechanism during dynamic driving cycle. Int. J. Hydrogen Energy 41, 4239-4250 (2016)

32. Lin, R., et al.: Investigating the effect of start-up and shut-down cycles on the performance of the proton exchange membrane fuel cell by segmented cell technology. Int. J. Hydrogen Energy 40, 14952-14962 (2015). https://doi.org/10.1016/j.ijhydene.2015.09.042

33. Yu, Y., et al.: A review on performance degradation of proton exchange membrane fuel cells during startup and shutdown processes: causes, consequences, and mitigation strategies. J. Power Sources 205, 10-23 (2012)

34. Linse, N.: Start/stop phenomena in polymer electrolyte fuel cells, pp. 1-221, PhD Thesis (2012)

35. Zhao, M., et al.: Influence of membrane thickness on membrane degradation and platinum agglomeration under long-term open circuit voltage conditions. Electrochim. Acta 153, 254-262 (2015). https://doi.org/10.1016/j.electacta.2014.12.024

36. Wang, X., Kumar, R., Myers, D.: Effect of voltage on platinum dissolution relevance to polymer electrolyte fuel cells. Electrochem. Solid-State Lett. 9, A225-A227 (2006)

37. Ferreira, P.J., et al.: Instability of $\mathrm{Pt} / \mathrm{C}$ electrocatalysts in proton exchange membrane fuel cells. A mechanistic fuel cells. J. Electrochem. Soc. 152, A2256-A2271 (2005)

38. Chung, C.G., et al.: Degradation mechanism of electrocatalyst during long-term operation of PEMFC. Int. J. Hydrogen Energy 34, 8974-8981 (2009)

39. Zhang, Y., et al.: Study of the degradation mechanisms of carbonsupported platinum fuel cells catalyst via different accelerated stress test. J. Power Sources 273, 62-69 (2015)

40. Maass, S., et al.: Carbon support oxidation in PEM fuel cell cathodes. J. Power Sources 176, 444-451 (2008)

41. Liu, M., et al.: Diagnosis of membrane electrode assembly degradation with drive cycle test technique. Int. J. Hydrogen Energy 39, 14370-14375 (2014)

Publisher's Note Springer Nature remains neutral with regard to jurisdictional claims in published maps and institutional affiliations. 